Unity Journal

Vol. III, 253-265, 2022

Doi: https://doi.org/10.3126/unityj.v3i01.43330

Prithvi Narayan Shah Research Center

Directorate General of Military Training, Nepali Army

Kathmandu, Nepal

\title{
UN Peace Operations: Diplomacy, Delivery and New Directions
}

\section{Narayan Prasad Wagle}

\begin{abstract}
This paper explains roles of diplomacy for better UN (United Nations) Peace Operations, major obstacles in the delivery of mandates of UN Peace Missions, inter alia, due to weaknesses in UN peace architecture and thematic new directions in the course of its evolution. The research methodology involves document analysis and review. The sources of data are UN documents on UN Peace Operations and UN Study reports on the same.It finds the inevitable role of diplomacy in leading discourses, designing and deciding mandates of missions. Due to the political nature of conflicts and dynamic nature of global politics, more effective diplomacy is needed both at global and local level. Reviewing UN peace architecture, it finds that UN Peace Operations are largely successful though beset by some key challenges. Further, it explains such thematic new directions as protection of civilians, women peace and security, concern about safety and security of peacekeepers, regionalism, building and sustaining peace, and growing demand for accountability and professionalism. Finally, some findings and implications for diplomats and peacekeepers involved in UN Peace Operations have been drawn.
\end{abstract}

Key words: UN peace operations, diplomacy, peace architecture, protraction of civilians, regionalism, sustainable peace, peace and security.

\section{Introduction}

The evolution of UN Peace Operations since 1947 has shown that its role in the maintenance of international peace and security has not only been expanding but also indispensable. Over the period it has been clear that politics, both domestic and international, is central to the resolution of disputes and success of UN peace operations. The UN peace architecture lies at the core of designing UN peace missions and delivering on mandates thereof, although it is affected by global political, economic and social structures and processes such as globalization or international system in vogue. The thin idea of peacekeeping during its innovation has advanced into a complex undertaking comprising new thematic directions. The first part of the articles defines concept of peace and UN peace operation. The second part deals with methodology. The third part of the article discusses roles of diplomacy in designing peace architecture in the long run and peace missions in the short run. In the fourth part, effectiveness of UN peace operations has been evaluated in delivering promises of peace. The fifth part explains new thematic directions in UN Peace Operations 
such as protection of civilians. The sixth part enlists findings and implications of the study. The article concludes with some observations.

\section{Introduction: Understanding Peace and Scope of UN Peace Op4rations}

No agreed or universal definition of peace exists in the peace studies scholarship. It is briefly explained for the purpose of this article. Second, UN Peace Operations that evolved in the last seven decades has been at times confusing in its scope, which is clarified in the subsequent paragraph in the light of Capstone doctrine.

\subsection{Understanding Peace}

Peace has always been among humanity's highest values--for some, supreme (Rummel, 1981) But, for deriving the meaning of peace, one is essentially guided by a theory or philosophy or a perspective. Even a single perspective or theory may lead to different meanings of peace depending on content, context, levels, agency, and so on.

In "Peace by peaceful means conflict transformation - the TRANSCEND approach", Johan Galtung (2007, 31p), the pioneer of positive peace, has recognized, "development a condition for peace: without development no peace." Thus, peace involves acting on structures - social, economic, political etc..

A variety of approaches view peace differently: most prominent ones are liberal peace, peace constructed through dialogue and emancipatory peace. In liberal theory of peace, the institutions of rule of law and human rights at home and democratic peace among nations form the basis of world peace. If liberal principles, practices and institutions generated domestic and international peace, prosperity, and respect for human rights, then their absence was (considered to be) responsible for conflicts (Jahn, 2021; Chapter 2; Fukuyana, 1989, 3, 15).

For constructivists, peace is socially constructed. Peace is mutually constituted by actors employing constitutive rules and social practices and can have multiple meanings for different actors based on their own communities of intersubjective understandings and practices (Jahn and Richmond, 2021, Chapter 3; Hopi, 1998, 174). Actors give meanings to peace in particular contexts through interactions.

Likewise, critical theories on peace can be understood as discourse on emancipatory peace. To understand the radical emancipation that peace building actually requires, one needs to engage with postcolonial, feminist, intersectional and environmental debates at a minimum in the context of variants of war and neoliberal and digital form of violence(Walls, 2021, Chapter 5, pp. 77-91)

For a deeper understanding of peace, it is possible to blend perspectives, for example, establishing liberal peace through social construction that may give variants of liberal peace. It is equally possible to hold emancipatory peace discourses within liberal peace framework

\subsection{Understanding Scope of UN Peace Operations}

An Agenda for Peace (UNGA, 1993) defined various terms of UN Peace Operations: preventive diplomacy, peacekeeping, peacemaking and peacebuilding. Apart from peacekeeping missions, special political missions are launched by the UN to support preventive deployment, peacemaking and peacebuilding tasks. 
The Capstone Doctrine clarifies these principles setting the limits for UN Peace Operations both in the use of force. (Coning \& et.al., 2008).

According to this doctrine, robust peacekeeping involves the use of force at the tactical level with the authorization of the Security Council and consent of the host nation and/or the main parties to the conflict.

Thus, the scope of UN Peace Operations has been widened encompassing peacekeeping operations to robust peacekeeping to special political missions.

\section{Methodology}

The research methodology involves document analysis and review. The sources of data are UN documents on UN Peace Operations and UN Study reports on the same. The categories of documents include policies, guidelines, handbooks, standards, resolutions and rules. The author draws meaning based on description of the content.

\section{Diplomacy}

Diplomacy, which is as old as human civilizations, has played a crucial role in managing relations among states and societies. In the evolution of multilateral conferences, institutions and regimes, it proved to be indispensable. Furthermore, in the functioning of these institutions and in the implementation of agreed norms and policies, the art of negotiation and compromise is invaluable.

\subsection{Diplomacy, Collective Security and Reforms}

The Peace of Westphalia, in 1648, brought to an end the Thirty Years' Wars in the Holy Roman Empire. The two treaties signed after protracted negotiations finally brought peace ending the tumultuous period that killed around eight million people in Europe.

In the 19th and 20th century, the three diplomatic efforts that ended wars through signing of treaties were respectively the Congress of Vienna, the Treaty of Versailles and the signing of UN Charter.

The signing of the UN Charter in San Francisco in 1945 ignited a hope for effective collective security system for two reasons: First it not only outlawed wars but also imposed general prohibition on the use of force or threat of use of force, and secondly it put in place mechanisms to respond to prohibited acts against international peace and security.

As Wilson (2014) has put forward, the requirements of collective security, which include institutional system, universality, commitment of major powers and acceptance of indivisibility of peace.

Although the United Nations fulfilled many of the requirements of viable collective security system, the emergence of Cold War made provisions of the Charter on Military Staff Committee and forces at the disposal of the Security Council for the Security Council interventions ineffective.

As a soft alternative between pacific settlements of disputes and forceful collective intervention, the young United Nations innovated peacekeeping.

Quite often, expectations for fulfilling tasks for which it was not innovated are imposed. Thus, long overdue task of diplomacy at the highest level is to make collective security system viable through United Nations reforms and reforms of the Security Council 
in particular. However, Crocker (2021) has categorized diplomatic strategies at par with three dimensions of conflicts, particularly from great power (American)perspective, which may lead to fragmented approaches beset by nationalism. After all, effective multilateralism propped by diplomatic collaborations among major powers continue to remain at a core of strengthening peace architecture and making real peace.

\subsection{Diplomacy, Decisions on, and design of, mandates of UN Peace Missions}

Both Brahimi Report (UN, 2000) and Report of High Level Independent Panel on Peacekeeping Operations (UN, 2015) identify the primacy of politics as major factors in the resolutions of the conflicts and its importance before, during and after UN Peace Operations in finding the lasting peace. It is the UN Security Council that authorizes the UN peace missions. The Security Council is essentially a political body in which national interests permeate and negotiated compromises are reached.

As mentioned by Jett (2019), in 1994, the President of the Security Council elaborated some bases of the establishment of peacekeeping operations, such as situation as a threat to international peace and security, possible roles of regional organizations, existence of ceasefire, political goal or possibility of political settlement etc. It signifies lack of institutional criteria.

The legal basis of UN peace missions is indirect. In fact, the actual parameters of any mandate are the result of negotiation among permanent five of the Security Council. Mandates sometimes suffer from too much ambiguity because of differing views of the influential powers.
Depending on their mandate, peace operations may be required to prevent conflicts, stabilize once occurred, implement peace deal and lead territories through transition. UN peacekeepers may have to engage in peacebuilding activities such as SSR(Security sector reform), DDR(disarmament, demobilization and reintegration) etc.

Former Secretary-General's Special Representative to Nepal (UNMIN) Ian Martin emphasized what he called "designer missions". Nadin (2014) further writes “ Martin's concept advocates a context sensitive approach, whereby missions are "designed according to the particularities of the peace process or conflict management objective they are to support, with maximum flexibility and scope for innovation". The problem with many UN peace operations is that they rely too heavily on template approaches, rather than country specific ones." Designer missions prioritize certain tasks at certain stages in the mission's lifecycle,

\section{Delivery of UN Peace Operations}

The implementation of Mandates can be evaluated at two layers: First, it can be judged in the broader international framework where actors other than the UN play a part, and second, it can be evaluated inside context of the UN peace architecture. The UN system as a whole remains in between the two.

\subsection{International Peace Architecture and Impact on Peace}

By international peace architecture, it is meant to indicate the overall framework of peace, which at least exists theoretically manifested in such tools as diplomacy, peacekeeping, mediation, law, peacebuilding, state-building, and global governance. Richmond (2021) has stated that a much broader international 
architecture has emerged in various stages, of which the liberal peace is just one component.

The six stages of peace he suggested are negative peace, liberal peace, positive peace, neo-liberal peace, post liberal peace and peace with global justice. For example, the layer five in the historical development of international peace architecture is defined by subalterns claims for equality, justice and sustainability utilizes methodological everydayism. Its components embrace social and participatory democracy, multilateral institutions, expanded human rights and human security. Indirectly, It suggests that big structures and processes such as globalization and inequality, international system in vogue and prevailing ideas like human rights or identity politics need to be taken into account if they have any impact in the effectiveness of UN Peace Architecture.

\subsection{UN Peace Architecture and Delivery of UN Peace Operations}

The Security Council, which is the highest political body on UN Peace Operations, decides on the mandates of every UN Peace Operation, once mandated, the UNGA takes on the financial decisions. However, the role of UNSG is critical because it is his detailed reports that guide decisions on mandates and financing. The top layer of UN Headquarters branches into two parts: the peacebuilding architecture and the peace operations architecture. The two interacts with one another though they are established for separate purposes. As Shimura (Thakur, Ramesh, 2001) writes "the role of the Secretary-General and the Secretariat in organizing and managing peacekeeping operations (PKOs) can be said to be unusually prominent, and it may exceed anything the founders of the United Nations had envisaged, especially since it concerns the field of the UN's central activity related to the maintenance of peace and security".

The Authority, Command and Control of UN Peacekeeping Operations (UNDPKO, 2019) further highlights on the structures and functions ofcomponents of UN Peacekeeping architecture with implications for effective delivery.

Till 2021, 71 UN peace operations have been mandated and 58 missions have accomplished their mandates so far. The quantitative achievement is commendable and this tool of peace and security pillar of the $\mathrm{UN}$ has proven indispensable. The continuity of the Missions that were established in 1948, frequent extension of mission's mandates, and some cases of relapse into conflicts suggest that more effective missions along with political solutions will be in demand.

Jett (2019) has mentioned a number of factors that lead to peacekeeping failures, including lack of standby arrangements, diversity of forces, national caveats. Quoting a 2017 report by the Center on International Cooperation at New York University, he has listed the causes of failures including, bureau mania of the UN Secretariat, unclear political strategy, lack of system coherence, disregard to empowerment of field missions as well as inadequate resources. Accountability deficit and low level of professionalism on the part of mission leadership and peacekeepers also contribute to diminished outcomes.

As Havard Hegre et.al. (2018) concludes" UN peacekeeping is clearly a cost-effective way of increasing global security", its worthiness is clear and delivery evident.

\section{New Directions in UN Peace Operations}

In about the last seven decades, the UN peace operations have evolved significantly both in 
doctrines, principles and parameters as well as thematic areas of focuses. This section is devoted to identify and explain the emerging and evolving themes (not an exhaustive list) that have implications for both structures and functions of UN peace missions.

\subsection{Protection of Civilians}

The pre-1988 missions were largely lightly armed ones engaged just in monitoring ceasefires and reporting them. They had no explicit reference to protection of civilians in their mandates.

In 1999, the United Nations Security Council passed its first resolution on the protection of civilians (S/RES/1265, 1999) and, for the first time, gave a peacekeeping operation the mandate to take necessary action to protect civilians under imminent threat of physical violence (S/RES/1270, 1999 on the United Nations Mission in Sierra Leone, UNAMSIL). The first DPKO/DFS Policy on the Protection of Civilians in United Nations Peacekeeping came out in 2015.

However, at the operational and tactical level, the progress was limited during the period. That meant that there was no standard pre-deployment training, the performance measures and no accountability frameworks.

As POC (protection of civilians) policy (UNDPKO, 2019) provides the conceptual framework, guiding principles and key considerations for the implementation of protection of civilians (POC) mandates. The 2020 POC Handbook is an operation tool.

The three tiers of POC action are: Tier I: Protection through dialogue and engagement, Tier II: Provision of physical protection and Tier III: Establishment of a protective environment. While the second pillar is more security driven, the remaining two tiers point to broader political, legal and security processes.

Although the two ideas pertain to peacekeeping, the responsibility to protect and the protection of civilians are distinct but inevitably related ideas (Williams, 2016) $\mathrm{R} 2 \mathrm{P}$ is to prevent mass atrocity crimes. POC is derived from IHL, IHRL and IRL.

Pointing to the operational aspect of the protection of civilians, Gorden (2013) stresses that opportunities for and pressures on military actors to develop more specific capacities and approaches in this field have grown. Further, highlighting the need of normative development, Siobhan (2021) argues that legal obligations to protect that are derived largely from international human rights law, international humanitarian law, and the International Law Commission's Draft Articles on the Responsibilities of International Organizations are comparatively weak.

\subsection{Women, Peace and Security(WPS) Agenda in Peacekeeping}

In general, the UN DPKO(United Nations Department of Peacekeeping Operations) and other stakeholders in WPS agenda have taken two approaches: "the participation of women in their peacekeeping forces, and the protection of women"(Karim,S., 2017).

The multidimensional peacekeeping missions were mandated more broadly assigning the missions with such tasks as reforming judicial and security institutions as well as monitoring of human rights and elections. An Agenda for Peace redefined peacekeeping making it possible to incorporate gender as one component of UN peace missions. 
The UNSCR 1325(UNSC,2000) emphasized the role of women in prevention and resolution of conflicts. It urges participation of women in all stages and mechanism of conflict resolution process. Its contribution is the insertion gender perspectives in $\mathrm{UN}$ activities.

The Windhoek Declaration and the Namibia Plan of Action on Mainstreaming a Gender Perspective in Multidimensional Peace Support Operations, provided for gender mainstreaming and gender balancing in UN peace operations.

In line with zero tolerance policy to SEAHVs(sexual exploitation, abuses, harassment and violence), the UNSCR 1820(UNSC, 2008) enunciates the policy of zero tolerance of sexual exploitation and abuse in UNPKOs. It urges troops and police contributing countries to take preventive action. Likewise, HIPPO include a special section on WPS.

The early female police units employed in peacekeeping were from South Asia. On January 31, 2007, India deployed 105 Indian Police Women to the UN Mission in Liberia (UNMIL) "(Karim, 2017)..

According the UN Women statistics (UN,2021), the UN exceeded the 2020 targets set in the Uniformed Gender Parity Strategy although it lagged behind the military troops, which is due to lack of gender parity deficit in the traditional armies of Member States.

As of 31 December 2020, three women served in the most senior military positions in the field and four women led United Nations police components.

\subsection{Regionalism}

The UN Charter (UN, 1945) envisages role of regional arrangements or agencies in maintenance of international peace and security as long as they are consistent with the principles and purposes of the UN Charter. For the settlements of local disputes, the regional arrangements or agencies must seek pacific methods

The UNSC authority for traditional peacekeeping is not necessary as there is no prima facie violation of Article 2 (4). However, in the execution of Chapter VII mandate, UNSC authorization may be required.

On the other hand, the regional agencies and arrangements must have included peace and security within their scope and need to possess capabilities and mechanisms for peace operations. Some of the regional organizations of this nature include Organization for Security and Cooperation for Europe, African Union, Economic Community of West African States, the Arab League, and the European Union.

Regional peacekeeping, has not so far been very effective alternative. Coleman (2011) notes that sub-Saharan African states have distanced themselves from long-term autonomous regional peacekeeping, and currently favor explicitly interim missions that are a prelude rather than an alternative to UN peacekeeping. For reasons of resources and capabilities, UN peacekeeping is preferred over regional peacekeeping. Koops et.al. (2015:30pp) has stated that "While these partnerships have often been fruitful, some have generated considerable tension and debates, particularly about how to interpret Chapter VIII of the UN Charter (with respect to Regional Arrangements) and 
what a strategic relationship between the UN and a regional arrangement should entail in practice."

\subsection{Accountability}

The mission leadership, military, police and civil personnel as well as those supporting the missions from the UN Headquarter, the Secretariat need to account for the gaps and under performance or misdeeds so as to endure correction, sanctions, lesson learning and other accountability measures. However, the governance structure of the mission together with provisions of immunities and privileges put some impediments on the straight forward methods of holding accountable the personnel of diverse nature loyal to the Member.

In 2018, the Security Council unanimously adopted a resolution 2436(UNGA, 2018) with a view to improving behavior, leadership and accountability in UN peacekeeping. Regarding accountable mission leadership, the resolution has laid emphasis on transparent selection processes that are based on merit, competence and the needs of the mission, training and monitoring programs for selected and prospective leadership, and developing a cadre of experienced leadership for future senior leadership positions. The resolution has suggested a range of accountability measures in proportion to performance failures.

Regarding sexual abuse and exploitation by peacekeepers, the resolution refers to the zerotolerance policy. The three-pronged strategy of prevention, enforcement and remediation with victim centric approach is considered to be effective and the role of Member States in vetting and training military personnel has been emphasized.
For enhancing accountability in practice, Namie Di Raza (2019) has made three recommendations for the UN Secretariat for enhancing POC accountability: working towards a more cohesive accountability structure, strengthening independent, dedicated and transparent accountability tools, and enforcing consequences. Likewise, ccountability and performance, the fifth component in action for peace (UNDPKO, 2018), is accompanied by a number of collective commitments focusing on accountable leadership, integrated performance policy framework, performance data etc.

\subsection{Safety and Security of Peacekeepers}

Peacekeeping environment in recent times feature a number of risks: armed groups, terrorists, organized crime, street gangs, criminal and political exploitation, and other threats. Chapter VI type missions without Security Council authorization to use all necessary means often fail to maintain a robust posture. Apart from it, a range of factors influence safety and security of peacekeepers. As identified in the 2017 report" Improving the Security of United Nations Peacekeepers" a number of elements have been identified. Leadership both at headquarters and mission must be proactive, adaptive and committed to respond appropriately both forcibly and politically. The training of the peacekeepers, their mastery over local language, the equipment $\mathrm{s}$ they have, the new technologies that are used all pertain to the security of peacekeepers. Once the casualties and physical injuries occur, the arrangement of medical services and speedy rescue can save lives further. The speed of decisions on logistics from the headquarter administration do matter in robust response to the threats. 
Further, the Security Council Resolution 2418(UNSC, 2018) has addressed various aspects of safety and security of peacekeepers. It has emphasized the obligations of the host state to comply with force agreements including facilitation of entry and movement of personnel and equipment within the country. In addition, the host state is under obligation to investigate and prosecute those who attacked the peacekeepers. Utilization of Light Coordination Mechanism and development of well-defined medical standards for peacekeeping are also recommended.

As per the UN statistics, 4147 peacekeepers have laid down their lives till September 2021. Mix of terrorism and ethnic violence exacerbates the situation.

Aptly, the newly floated A4P plus agenda has incorporated accountability to peacekeepers at the heart of the shared efforts.

Hoever, as Kaempf(2018) has highlighted, the dilemma between the two norms" POC and the security of peacekeepers in the context of asymmetric warfare has no easy solution.

\subsection{Building and Sustaining Peace}

An agenda for peace has defined and incorporated both peacekeeping and peace building under broader notion of UN peace operations.

The twin resolutions, UNGA resolution 70/262(UNGA, 2016) and UNSCR 2282(UNSC, 2016), has reviewed UN peace building architecture and has mentioned various strategies for sustaining peace. It has defined "sustaining peace", as a goal and a process to build a common vision of a society, ensuring that the needs of all segments of the population are taken into account, which encompasses activities aimed at preventing the outbreak, escalation, continuation and recurrence of conflict, addressing root causes, assisting parties to conflict to end hostilities, ensuring national reconciliation, and moving towards recovery, reconstruction and development, and emphasizing that sustaining peace is a shared task and responsibility that needs to be fulfilled by the Government and all other national stakeholders, and should flow through all three pillars of the United Nations engagement at all stages of conflict, and in all its dimensions, and needs sustained international attention and assistance. Thus, it is clear that building and sustaining peace is guided by the principles of inclusion, reconstruction and development, shared responsibility and partnership, and sustained efforts.

In the 2020 Report of the Secretary General to the General Assembly (UNGA, 2020), the progress across the aforementioned four pillars is mixed with the financial component registering the least achievement.

Even more durable peace would be through prevention based on "the principle-sustained, inclusive and targeted "(United Nations and World Bank, 2018)

\subsection{Professionalism and Conduct}

The evaluation of professionalism is to be done on the bases of integrated performance policy framework, standards of performance and set benchmarks for the jobs at hand. The most effective way of enhancing professionalism of peacekeepers is through various types of training: pre-deployment, functional and in mission packages. Multitude of subjects, length of time and complexity of the subjects have posed challenges for designing and conducting efficient training programs. The 
multidimensional and complex peacekeeping missions in risky zone demand a variety of skills, knowledge and attitudes in order to be professional and efficient in a coordinated manner.

Lapsatis Isidoros(2019) has identified that many of the peacekeepers do not receive the right training if any training at all before they are deployed. In addition, evidence presented shows that current UN peacekeeping training material is not adequately preparing peacekeepers.

The peacekeepers are required to:

respect local laws, customs and practices, treat host country inhabitants with respect, courtesy and consideration, and act with impartiality, integrity and tact.

The UN has a three-pronged strategy to address all form of misconduct including sexual exploitation and abuse: prevention of misconduct, enforcement of UN standards of conduct and remedial action. The methods of implementation of this strategy, as stated by the UN, involve such tools as training, awareness raising, investigations, assistance to victims and standards of conduct. The UN has a zero-tolerance policy with respect to sexual exploitation and abuse.

However, the problem is that different countries have different laws on the same crimes and quite often penalties imposed to the abusers are not reported.

Similarly, human rights due diligence policy (UNGA/UNSC, 2013) requires UN entities risk assement, transparency and implementation framework.

\section{Findings of the Study and the Implicitizations for diplomats and peacekeepers}

Based on this study, the following findings have been enumerated and associated implications have been drawn for the effective participation of TPCCs, diplomats engaged around peace operations and peacekeepers:

i. Diplomacy can design and redesign UN peace architecture in the long run and design and redesign mandates of missions in the short run. So, both diplomats and peacekeepers from TPCCS and major powers and developed countries must coordinate closely in their capitals and UN HQ to understand the whole process better and to work toward the common goals of effective peacekeeping. . Coordinated efforts among peacekeeping professionals are vitally important for peacekeeping effectiveness.

ii. The UN peace architecture must be adjusted according to the changing functional needs, and in cognizance of global structures, institutions and processes that impact upon peace operations.

iii. The notion of protection of civilians is gradually becoming the central theme of the UN peacekeeping operations. This should be reflected in the training programs and orientation. Further normative development is essential for a clear legal standing while executing it.

iv. Inclusion of women in peacekeeping troops is growing in a slower pace in view of the promises made. TPCCS must prepare a plan to include gender training and mainstream gender and contribute to the goals of gender parity, gender sensitivity and mainstreaming in 
peacekeeping troops.

v. Safety and security of peacekeepers and performance are interrelated. The safety and security of peacekeepers must be placed high on the agenda in negotiation of mandates, resources and training. The training programs should reflect it including handling of high technologies.

vi. The emphasis has gradually shifted towards building and sustaining peace. This has implications for peacekeeping operations and mission leadership. The resources, expertise and mission transitions should be managed accordingly.

vii. Trainings of peacekeepers are fundamental to the success of peacekeeping. TPCCS(troops and police contributing countries) countries can cooperate to promote their common interests including catalysing and enabling research and training institutes on peacekeeping. Regional peace institutes may be of great importance. For Delivery of mandates, the peacekeeping professionals must demonstrate general skills, job-specific skills and commitment to core values.

\section{Concluding Remarks}

Peace means positive in the sense that it is constructed through dialogue and achieved through transformation of structures. It is not merely absence of dissent voices or absence of violence It is multidimensional and multilayered wholistic phenomenon.

The international peace architecture is supposedly complex and evolving. The UN peace architecture has to be understood in the larger context of international system, structures and processes.
The evolution of UN peace Operations in the last seven decades has been encouragingly positive despite numerous failures and challenges. The evolving themes within peace operations paradigm have indicated where we need more effectiveness - the centrality of protection of people, the human security. Its limitations and failures also point to the needed reforms in various parts of the UN System. Sustainable peace can be achieved through nationally and locally owned peace process with high priority to political solution though diplomatic efforts.

\section{References}

Coleman, K. (2011). Innovations in African Solutions to African Problems: The Evolving Practice of Regional Peacekeeping in Sub Saharan Africa. CUP online.

Coning, C. D., \& et.al. (2008). Principles and Guidelines for UN Peacekeeping Operations, 2008. UNOCHA. Retrieved 2 December, 2021, from https:/www.unocha.org/sites/ dms/Documents/DPKO\%20Capstone \%20 doctrine \%20(2008).pdf

Crocker, C. A., Hamsen, F., \& AALL, P. (2021). Diplomacy and Future of World Order. Washington D.C.: Georgetown University.

DPKO/DFS. (2010). Training for all United Nations. Retrieved 30 November , 2021, from http://dag.un.org/bitstream/ handle/11176/401032/2010.20\%20 D P K O $\mathrm{DF} \mathrm{S}_{-} \mathrm{POL}_{-} \mathrm{Train}$ ing forallUNPKPersonnel_1 May 2010 . pdf? sequence $=1 \&$ is Allowed $=\mathrm{y}$

Gorden, S. (2016). The Protection of Civilians: An Evolving Paradigm? International Journal of Security and Development,2(2):40. Retrieved from https://www.stabilityjournal.org/ articles/10.5334/sta.cb/, 27 November, 2021

Hegre, H. (2018). Evaluating the Conflict Reducing Effects of UN Peacekeeping Oprations. The Journal of Politics 81(1): 215- 
232.

Jabri, V., \& Richmond, O. P. (2021). Critical Theories and Politics of Peace; The Oxford Handbook of Peacebuilding, Statebuilding and Peace Formation. (O. P. Richmond, \& V. Gëzim, Eds.) London: OUP.

Jahn, B. (2021). Liberal Internationalism (chapter.2). In Richmond, O.P. (ed.)The Oxford Handbook of Peacebuilding, Statebuilding and Peace Formation. London: OUP.

Jett, D. (2019). Why Peacekeeping Fails. Pennsylvania: Pennsylvania State University.

Karim, S., \& Beardsley, K. (2017). Equal Opportunity Peacekeeping; Women, Peace and Security in the Post-Conflict States. USA: OUP.

Koops, \& et.al. (2015). The Oxford Handbook of UN Peacekeeping Operations. London: OUP.

Lapsatis, I. (2019). The efficiency of preparing UN peacekeepers: problems in contemporary peacekeeping. Retrieved 30 November, 2021, from https://www.vdu.lt/cris/ handle/20.500.12259/79152

Nadin, P. (2014). An Agenda for More Focused Peacekeeping Mandates. online. Retrieved from https:/ourworld.unu.edu/ en/an-argument-for-more-focused-unpeacekeeping-mandates, 27 November 2021

Richmond, O. (2021). The Evolution of International Peace Architecture. Retrieved from Cambridge University Press: https:// www.cambridge.org/core/journals/europeanjournal-of-international-security/article/ evolution-of-the-international-peace-archite cture/729C18031374E33A7A36DA968197 2C06, 27 November 2021

Rummel, R. (1981). The Just Peace (Vol. 5). California: Sage Publication.

Sebastian, K. (2018). Saving Soldiers or Civilians? UK: OUP.

Shimura, H. (2001). The Role of UN secretariat in Organizing Peacekeeping; United Nations Peacekeeping Oprations;Ad hoc Missions, Permanent Engagements. (R. Thakur, \& A. Schanabel, Eds.) New York: United Nations University Press.

UN. (24 October, 1945). The UN Charter. Retrieved from : https://www.refworld. org/docid/3ae6b3930.html [accessed 30 November 2021]

UN. (2000). Report of the Panel on United Nations Peace Operations (Brahimi Report) [A/55/305]. UNGA. Retrieved 30 November, 2021, from http://www.un.org/en/ga/search/ view_doc.asp

UN. (2009). C-34 Report. Retrieved 30 November, 2021, from https://casquebleu. org/index.php?title=Special_Committee_on Peacekeeping_Operations\#Recent_C-34_reports

UN. (2015). Report of the Independent HighLevel Panel on Peace Operations. Retrieved 30 November, 2021, from http://www.un.org/ en/ga/search/view_doc.asp

UN. (2018). Action for Peacekeeping. Retrieved 30 November , 2021, from https://peacekeeping. un.org/en/action-for-peacekeeping-a $4 p$

UN. (2021). 2021 e-Guide for Staff Supporting UN Peace and Security Pillar (5428Kb). Retrieved 30 November, 2021, from http://dag.un.org/ bitstream/handle/11176/89593/2021\%20 e-Guide $\% 20$ for $\% 20$ Staff $\% 20$ Supporting $\% 20$ UN\%20Peace\%20and\%20Security\%20Pillar. pdf? sequence $=4 \&$ isAllowed $=y$

UN. (2021). Facts and figures: Women, peace, and security. Retrieved 30 November, 2021, from https://www.unwomen.org/en/what-wedo/peace-and-security/facts-and-figures

UN. (n.d.). Ten Rules. Retrieved 30 November, 2021, from https://pseataskforce.org/ uploads/tools/tenrulescodeofpersonalconductforbluehelmets_undpko_english.pdf

UN, G. A. (1993). An Agenda for Peace: resolution/ adopted by the General Assembly,A/ 
RES/47/120B. UNGA. Retrieved from : https://www.refworld.org/docid/4a54bbdad. html [accessed 29 November 2021]

UNDPKO. (2019). Authority, Command and Control in. Retrieved 30 November, 2021, from https://police.un.org/sites/ default/files/2019.23_policy_on_authority_ command_and_control_25_october_2019.pdf

UNDPKO. (2019). The Protection of Civilians in UN Peacekeeping. Retrieved 30 November, 2021, from https://peacekeeping.un.org/sites/ default/files/poc_policy_2019_.pdf

UNDPKO. (2020). Handbook: The Protection of Civilians in the United Nations Peacekeeping. USA: United Nations Press.

UNGA. (2016). Resolution 70/262. UNGA. Retrieved 30 Nov., 2021, from https:// www.un.org/en/development/desa/ population/migration/generalassembly/docs/ globalcompact/A_RES_70_262.pdf

UNGA. (2020). Peacebuilding and Sustaining Peace: Report of the Secretary General. Retrieved 30 November, 2021, from https:// www.un.org/en/ga/search/view_doc. asp?symbol=a/72/707

UNGA/UNSC.(2013). Human rights due diligence policy on United Nations support to nonUN Security Forces, A/67/775-S/2013/110. Retrieved 30 November, 2021, from https://www.ohchr.org/Documents/ HRBodies/SP/AMeetings/20thsession/ IdenticalLetterSG25Feb2013 en.pdf

UNSC. (1999). Resolution 1265. Retrieved 30 November, 2021, from https://digitallibrary. un.org/record/285718? $1 \mathrm{n}=\mathrm{en}$

UNSC. (2000). Resolution 1325. Retrieved 30 Nov., 2021, from https://peacemaker. un.org/sites/peacemaker.un.org/files/ SC_Resolution WomenPeaceSecurity_ SRES1325\%282000\%29\%28english_0.pdf

UNSC. (2008). Resolution 1820. Retrieved
30 Nov., 2021, from http://unscr.com/en/ resolutions/doc/1820

UNSC. (2016). 2282. Retrieved 30 Nov., 2021, from https://www.securitycouncilreport.org/ atf/cf/\%7B65BFCF9B-6D27-4E9C-8CD3CF6E4FF96FF9\%7D/s_res_2282.pdf

UNSC. (2018). Resolution 2418. Retrieved 30 November, 2021, from https://digitallibrary. un.org/record/1627990? ln=en\#record-filescollapse-header

UNSC. (2018). Resolution 2436. Retrieved 30 Nov., 2021, from https://undocs.org/S/ RES/2436(2018)

Wallis, J. (2021). The Social Construction of Peace (chapter 5). In Visoka, G. \& Richmond, O.P. eds.) The Oxford Handbook of Peacebuilding, State Building and Peace Formation. London: OUP.

Webel, C., \& Galtung, J. (2007). Handbook of Peace and Conflict Studies. London: Routledge.

Williams, P. D. (2016). Saving Individuals frrom the Scourge of War: Complementarity and Tension between R2P and Humanitarian Action. In Bellamy, A. \& Dunne, T. (eds) The Oxford Handbook of the Responsibility to Protect. London: OUP.

Wills, S. (2016) In Weller, M., Willmot, H. Mamiya, R. \& Sheeran, S, (eds.) Protection of Civilians; International Responsibility for Ensuring the Protection of Civilians. Online: OUP. Retrieved from https:// oxford.universitypressscholarship. c o m / v i e w/ 10 . $10096 /$ acprof:oso/9780198729266.001.0001/acprof9780198729266-chapter-11

Wilson, G. (2014). The United Nations and Collective Security. London: Routledge. 